Advances in Research
9(5): 1-6, 2017; Article no.AIR.24726
ISSN: 2348-0394, NLM ID: 101666096
SCIENCarch
SCIEDOMAIN international
www.sciencedomain.org

\title{
Exploration of the Antimicrobial Properties of Ficus exasperata Leaves from Akure Metropolis
}

\author{
S. I. Awala ${ }^{1^{*}}$, O. E. Ajayi ${ }^{1}$, O. A. Alabi ${ }^{1}$, O. Ajayi ${ }^{1}$ and O. T. Olalekan ${ }^{2}$ \\ ${ }^{1}$ Department of Microbiology, Federal University of Technology, P.M.B. 704, Akure, Nigeria. \\ ${ }^{2}$ Department of Biochemistry, Federal University of Technology, P.M.B. 704, Akure, Nigeria.
}

Authors' contributions

This work was carried out in collaboration between all authors. Authors SIA and OEA designed the study, wrote the protocol and wrote the first draft of the manuscript. Authors OAA, OA and OTO managed the literature searches, analyses of the study and performed the spectroscopy analysis.

All authors managed the experimental process and author SIA identified the species of plant. All authors read and approved the final manuscript.

Article Information

DOI: $10.9734 / \mathrm{AIR} / 2017 / 24726$

Editor(s):

(1) Martin Michaelis, Centre for Molecular Processing and School of Biosciences, University of Kent, UK.

Reviewers:

(1) Lorna T. Enerva, College of Science, Polytechnic University of the Philippines, Philippines. (2) Monthon Lertcanawanichakul, School of Allied Health Sciences and Public Health, Walailak University, Thailand and School of Sciences, Walailak University, Thailand. Complete Peer review History: http://www.sciencedomain.org/review-history/19031

Original Research Article

Received $30^{\text {th }}$ January 2016 Accepted $20^{\text {th }}$ February 2016

Published $12^{\text {th }}$ May 2017

\section{ABSTRACT}

Aim: The study was conducted to explore the antibacterial and antifungal properties of the leaf extracts of Ficus exasperata (Sand paper tree) in vitro.

Study Design: Extracts from Ficus exasperata leaves were qualitatively screened for the phytochemical constituents, and their in vitro antimicrobial potency was evaluated against fourteen (14) fungal and bacterial isolates.

Results: The tested extracts contained tannins, flavonoids, terpenoids, alkaloids and cardiac glycosides whereas, saponin, steroids, phlobatannin and anthraquinone were absent. The acetone extract of the leaf demonstrated better antimicrobial activity against 10 of the test organisms. However, the highest antimicrobial activity $(31.27 \mathrm{~mm})$ was exhibited by the methanol extract against referenced culture of Staphylococcus aureus. In addition, the extracts also displayed better antibacterial than antifungal activity. The minimum inhibitory concentration (MIC) of the extracts ranged between $0.391-1.563 \mathrm{mg} / \mathrm{mL}$, with the acetone extract displaying lower MIC values.

Conclusion: The occurrence of the observed phytochemicals in the extracts of Ficus exasperata 
(Sand paper tree) could be involved in the antimicrobial efficacy of the plant. The results from this study thus supports the folkloric use of the plants. Additionally, the plant could also be exploited for the production of drugs especially for staphylococci infections.

Keywords: Medicinal plants; antimicrobial; phytochemicals; extracts; Ficus exasperata.

\section{INTRODUCTION}

For ages, mankind has faced a constant battle with infectious diseases. This has led to increased morbidity and mortality especially among population from developing countries. Many populations have adopted the traditional healthcare system as a way of preventing and treating diseases of microbial origin [1]. Traditional medicine remains the most sort after, as it is considered safer, affordable, and readily available [1].

Due to the upsurge in resistance to conventional drugs by microbial agents, novel antimicrobial agents from different biological sources have been sort after and reported to be effective in combating pathogenic organisms. The use of herbal remedies containing plants or part of plants has in recent years gained ground in developed countries [2]. Pharmaceutical companies have thus developed new antimicrobial drugs and also improved on the existing ones through the modification of their structures with a view to increasing their efficacy [3].

Ficus exasperata otherwise known as the sandpaper tree is native to tropical Africa [4]. The leaves of $F$. exasperata have been employed in folkloric medicine for the treatment of various diseases such as ophthalmic and oral infections, venereal diseases, parasitic infection (cutaneous, subcutaneous), leprosy, and malaria $[5,6]$. The study therefore investigates the claim of the antimicrobial potential of $F$. exasperata, in a bid to develop novel antimicrobials.

\section{MATERIALS AND METHODS}

\subsection{Collection and Preparation of Extracts from Leaves Samples}

The leaves of $F$. exasperata were collected from its tree at a building near Life Spring College, Apatapiti layout, Federal University of Technology, Akure, Ondo State (Latitude: 7.289N, Latitude: $5.150 \mathrm{E})$ Nigeria in the month of April, 2015. Samples of the leaves were taken to the Department of Crop, Soil and Pest, FUTA for authentication. Afterwards the leaves were cleansed with water, shade dried, grinded and stored in airtight container. Thereafter, the powdered leaves $(100 \mathrm{~g})$ of $F$. exasperata was weighed separately into different plastic containers and $1000 \mathrm{~mL}$ of $100 \%$ acetone and methanol added to the containers for extraction. Aluminium foil was placed on each container before covering. Each solution was allowed to stand for 3 days with continuous stirring. The extracts were thereafter obtained by filtering the solutions through a funnel fitted with a filter paper. The filtrates were thereafter evaporated to dryness at $50^{\circ} \mathrm{C}$ in a rotary evaporator (RE-52A; Union Laboratory, England) with $90 \mathrm{rpm}$ under reduced pressure. The obtained concentrated extracts were stored in dark at $4^{\circ} \mathrm{C}$ until further analysis.

\subsection{Phytochemical Screening of Leaf Extract of Ficus exasperata}

The plant extracts were subjected to qualitative phytochemical screening using standard protocols described by Odebiyi and Sofowora [7], Trease and Evans [8], and Harborne [9].

\subsection{Measurement of Antibacterial and Antifungal Activities of Leaf of Ficus exasperata}

Varying concentrations of the leaf extracts of F. exasperata $(3.125-100 \mathrm{mg} / \mathrm{mL})$ were prepared by dissolving different amount of the extracts in $5 \mathrm{~mL}$ of $30 \%$ tween 20 . For example, concentrations of 100,50 , and $25 \mathrm{mg} / \mathrm{mL}$ were prepared by dissolving 500,250 and $125 \mathrm{mg}$ of the extracts into $5 \mathrm{ml}$ of $30 \%$ tween 20 respectively. Afterwards the prepared extracts were sterilized by passing them through a $0.22 \mu \mathrm{m}$ millipore membrane filter. The agar well diffusion method as described by Schinor et al. [10] was employed in assessing the antimicrobial activity of $F$. exasperata leaf extracts. A total of 14 clinical and referenced microbial strains were used for the experiment. The test organisms were obtained from the Pathology and Clinical Laboratory (PATHCARE), Lagos State University 
Teaching Hospital, Lagos State, Nigeria and the Department of Microbiology, FUTA. Active broth cultures of the test organisms were prepared from stock cultures. To $5 \mathrm{ml}$ of nutrient broth 0.2 $\mathrm{ml}$ of bacterial culture was inoculated and incubated till it reached the turbidity equal to that of the standard $0.5 \mathrm{McF}$ arland solution measured at $600 \mathrm{~nm}$ which is equivalent to $10^{6}-10^{8}$ $\mathrm{CFU} / \mathrm{ml}$. Suspensions of fungal spores were prepared from fresh mature (5 days) cultures that grew at $26 \pm 1^{\circ} \mathrm{C}$ on a Sabouraud dextrose agar. Spores were rinsed with sterile distilled water. The suspensions were then adjusted to $10^{6}$ spores per/ml by microscopic enumeration with a cell counting hematocytometer. An aliquot of $100 \mu \mathrm{L}$ of bacterial and fungal solution was evenly spread on already solidified Mueller Hinton agar plates. Afterwards, wells of $7 \mathrm{~mm}$ diameter were bored in the solidified Mueller Hinton agar plates using a sterile cork-borer. Thereafter, an aliquot of $100 \mathrm{uL}$ of the sterilized extract was added into the bored agar wells. The plates were thereafter incubated at $37^{\circ} \mathrm{C}$ for 24 hour for bacteria and at $26 \pm 1^{\circ} \mathrm{C}$ for 48 to 72 hours for fungi. The plates were observed for clear zones of inhibition and the measurements were taken using a ruler calibrated in millimetres. Commercial antifungal drugs (clotrimazole, nystatin and gluseofluvin) and commercial antibacterial drug (ciprofloxacin (10 $\mu \mathrm{g})$, rocephin $(25 \mu \mathrm{g})$ ) were used as the positive control, while $30 \%$ tween 20 was used as the negative control. To determine the minimum inhibitory concentrations (MIC), the agar diffusion method described above was used to screen the antimicrobial effect of the different concentrations of extracts $(0.391-100 \mathrm{mg} / \mathrm{mL})$. The MIC value was determined by establishing visible growth of microorganisms. The boundary dilution without any visible growth was defined as the MIC for the tested microorganism at the given concentration.

\subsection{Statistical Analysis}

Experiments were carried out in triplicates were applicable. The results were expressed as mean \pm standard error of three values. Data analysis was carried out using the One Way Analysis of Variance (ANOVA) and treatment means were compared using New Duncan's Multiple Range Test (SPSS version 16). Differences were considered significant at $\mathrm{P}<0.05$.

\section{RESULTS}

Table 1 shows the presence of tannin, flavonoid, terpenoids, alkaloids and cardiac glycosides in
F. exasperata leaf extracts, and the absence of saponin, steroids, phlobatannin and anthraquinone.

Table 1. Qualitative phytochemical screening of $F$. exasperata leaf extracts

\begin{tabular}{llc}
\hline Phytochemical & \multicolumn{2}{c}{ Extracts } \\
\cline { 2 - 3 } & FEM & FEA \\
\hline Saponin & - & - \\
Tannin & + & + \\
Flavonoid & + & + \\
Steroids & - & - \\
Terpenoids & + & + \\
Alkaloids & + & + \\
Phlobatannin & - & - \\
Anthraquinone & - & - \\
Cardiac glycosides & & \\
Legal test & + & + \\
Keller kiliani & + & + \\
Salkowski & + & + \\
Liberman test & + & + \\
\hline \multicolumn{1}{l}{ Keys: FEA: Acetone leaf extract of F. exasperata; } \\
FEM: Methanol leaf extract of F. exasperata
\end{tabular}

The antimicrobial activity of the leaf extracts of $F$. exasperata showed that the acetone leaf extract exhibited better activity against most of the test organisms used for the study (Table 2). However, the highest antimicrobial activity (31.27 $\mathrm{mm}$ ) was exhibited by the methanol extract of $F$. exasperata against referenced Staphylococcus aureus and this was found to be slightly higher that observed in the acetone extract $(29.40 \mathrm{~mm})$ against the same organism. In like manner, the leaves extracts displayed better antibacterial than antifungal activity. The antifungal activity of the acetone extract of the plant was however a better than that of the methanol extract.

Upon comparison of the activities of the leaf extracts against organism with Gram reaction positive and Gram negative bacterial isolates, the Gram positive organism were more susceptible than the Gram negative organism in most cases. The extracts antibacterial activity was comparatively better than that of the commercial antibacterial drugs in most of the tested organisms. Reverse was the case for the commercial antifungal drugs as they exhibited better activity than the extracts. The acetone extract of $F$. exasperata was found to exhibit lower minimum inhibitory concentration values than the methanol extracts. The results are displayed in Table 3. 
Table 2. Antimicrobial activity of leaves extracts of $\boldsymbol{F}$. exasperata and commercial drugs

\begin{tabular}{|c|c|c|c|c|c|c|c|}
\hline \multirow[t]{2}{*}{ Test organism } & \multicolumn{7}{|c|}{ Zone of inhibition (mm) } \\
\hline & FEA & FEM & CPX & $\mathbf{R}$ & CLOT & GRIS & NYST \\
\hline Salmonella typhi (ATCC 33489) & $15.20 \pm 0.12^{c}$ & $12.43 \pm 0.18^{a}$ & $12.27 \pm 0.15^{\mathrm{a}}$ & $14.30 \pm 0.12^{b}$ & NT & NT & NT \\
\hline Salmonella typhi & $18.43 \pm 0.18^{c}$ & $12.47 \pm 0.15^{\mathrm{a}}$ & $12.40 \pm 0.23^{\mathrm{a}}$ & $14.37 \pm 0.20^{b}$ & NT & NT & NT \\
\hline Staphylococcus aureus (ATCC 43300) & $29.40 \pm 0.17^{c}$ & $31.27 \pm 0.15^{d}$ & $14.40 \pm 0.12^{\mathrm{a}}$ & $15.50 \pm 0.17^{b}$ & NT & NT & NT \\
\hline Staphylococcus aureus & $27.33 \pm 0.24^{b}$ & $28.40 \pm 0.12^{c}$ & $15.43 \pm 0.20^{d}$ & $12.50 \pm 0.12^{\mathrm{a}}$ & NT & NT & NT \\
\hline Escherichia coli (ATCC 35218) & $22.20 \pm 0.12^{b}$ & $15.53 \pm 0.15^{\mathrm{a}}$ & $11.20 \pm 0.12^{b}$ & $14.27 \pm 0.15^{\mathrm{c}}$ & NT & NT & NT \\
\hline Escherichia coli & $17.50 \pm 0.26^{\mathrm{ab}}$ & $15.60 \pm 0.17^{\mathrm{ab}}$ & $12.50 \pm 0.23^{\mathrm{ab}}$ & $49.97 \pm 36.67^{\mathrm{a}}$ & NT & NT & NT \\
\hline Pseudomonas aeruginosa (ATCC 27853) & $12.27 \pm 0.15^{c}$ & $15.40 \pm 0.12^{\mathrm{b}}$ & $15.43 \pm 0.15^{\mathrm{a}}$ & $16.33 \pm 0.18^{b}$ & NT & NT & NT \\
\hline Shigella dysenteriae & $17.40 \pm 0.21^{\mathrm{a}}$ & $16.30 \pm 0.12^{b}$ & $14.40 \pm 0.12^{b}$ & $14.27 \pm 0.15^{\mathrm{c}}$ & NT & NT & NT \\
\hline Bacillus cereus & $15.60 \pm 0.17^{c}$ & $20.40 \pm 0.12^{d}$ & $12.33 \pm 0.18^{\mathrm{a}}$ & $14.53 \pm 0.20^{b}$ & NT & NT & NT \\
\hline Bacillus subtilis & $21.30 \pm 0.12^{d}$ & $12.43 \pm 0.15^{a}$ & $14.33 \pm 0.15^{\mathrm{b}}$ & $15.50 \pm 0.12^{c}$ & NT & NT & NT \\
\hline Candida albicans & $18.37 \pm 0.23^{d}$ & $10.27 \pm 0.15^{b}$ & NT & NT & $16.65 \pm 0.68^{c}$ & $20.50 \pm 0.29^{e}$ & $6.40 \pm 0.21^{\mathrm{a}}$ \\
\hline Aspergillus niger & $15.60 \pm 0.17^{b}$ & $3.47 \pm 0.20^{a}$ & NT & NT & $22.33 \pm 0.33^{d}$ & $21.67 \pm 0.33^{d}$ & $17.47 \pm 0.32^{c}$ \\
\hline Aspergillus flavus & $12.40 \pm 0.17^{\mathrm{c}}$ & $3.30 \pm 0.12^{a}$ & NT & NT & $25.00 \pm 0.15^{\mathrm{e}}$ & $9.77 \pm 0.15^{\mathrm{b}}$ & $18.73 \pm 0.22^{d}$ \\
\hline Aspergillus fumigatus & $13.30 \pm 0.17^{c}$ & $5.30 \pm 0.15^{\mathrm{a}}$ & NT & NT & $35.67 \pm 0.44^{e}$ & $9.33 \pm 0.44^{b}$ & $20.57 \pm 0.30^{d}$ \\
\hline
\end{tabular}


Table 3. Minimum inhibitory concentration $(\mathrm{mg} / \mathrm{ml})$ of leaf extracts of Ficus exasperata

\begin{tabular}{lll}
\hline Test organisms & \multicolumn{2}{c}{ MIC $(\mathbf{m g} / \mathbf{m L})$} \\
\cline { 2 - 3 } & FEA & FEM \\
\hline $\begin{array}{l}\text { Salmonella typhi } \\
\text { (ATC 33489) }\end{array}$ & 0.781 & 0.781 \\
Salmonella typhi & & \\
Staphylococcus aureus & 0.391 & 1.563 \\
(ATC 43300) & 0.391 & 0.781 \\
Staphylococcus aureus & 0.391 & 1.563 \\
Escherichia coli & 0.391 & 0.781 \\
(ATC 35218) & & \\
Escherichia coli & 0.391 & 0.391 \\
Pseudomonas aeruginosa & 0.781 & 0.781 \\
(ATC 27853) & & \\
Shigella dysenteriae & 0.781 & 1.562 \\
Bacillus cereus & 0.391 & 0.391 \\
Bacillus subtilis & 0.391 & 1.562 \\
Candida albicans & 0.391 & 0.391 \\
Aspergillus niger & 0.391 & 0.391 \\
Aspergillus flavus & 0.391 & 1.563 \\
Aspergillus fumigatus & 0.391 & 1.563 \\
\hline \multicolumn{2}{l}{ Keys: FEA: Acetone leave extract of F. exasperata; } \\
FEM: Methanol leave extract of Ficus exasperata
\end{tabular}

\section{DISCUSSION}

Plants remain an inexhaustible source of novel antimicrobials. Africa with its tropical and subtropical climate is richly blessed with an array of plants that have naturally acquired secondary metabolites in order to survive the harsh environment [1,11]. Compounds with antimicrobial properties that also offer protection against drug resistant microorganisms have been isolated from medicinal plants [12,13]. The present study investigated the secondary metabolite profile and antimicrobial efficacy of leaves of $F$. exasperata.

The presence of the observed secondary metabolites in the leaf extracts validates the medicinal potentials of this plants as these compounds have been reported to play a protective role against pathogenic organisms [13]. The absence of saponin, steroids, phlobatannin and anthraquinone in the extracts might be attributed to solubility of the compounds in the extraction solvent used.

The antimicrobial activity of the extracts could be attributed to the observed phytochemicals in the extracts. In addition, the variation observed in the antimicrobial activity of the extracts might be linked to differences in the type and amount of phytochemicals present in the extracts. The structural differences in the cell wall of Gram positive and Gram negative bacteria may account for the higher susceptibility of Gram positive bacteria to the plant extracts. The complexity in the cell wall Gram negative bacteria gives them better buffering capacity thus making their cell wall less impermeable, whereas Gram positive bacteria have only an outer peptidoglycan cell wall which makes them more susceptible [14].

The higher antibacterial activity demonstrated by the extracts than antifungal activity is in consonance with findings of several authors $[15,16]$ that have reported higher sensitivity of bacteria to antimicrobials. The chitinous cell wall of fungi promotes lesser susceptibility to antimicrobials than bacteria [17]. Antibiotics have been mostly reported to produce better performance against microorganisms than plants as a result their higher purity and smaller molecular sizes which aid their penetration into the cell wall of the organisms [18]. The better activity produced by the extract suggests that they can be explored for potent antimicrobial compounds.

\section{CONCLUSION}

The plant extracts produced an effective performance against the growth of the tested organisms especially Staphylococcus aureus. The plant extracts could therefore be exploited for the production of antimicrobial drugs especially for staphylococci infections.

\section{COMPETING INTERESTS}

Authors have declared that no competing interests exist.

\section{REFERENCES}

1. Mahomoodally MF. Traditional medicines in Africa: An appraisal of ten potent African medicinal plants. Evidence-Based Complementary and Alternative Medicine; 2013. Article ID 617459, 14 pages.

2. Chintamunnee V, Mahomoodally MF. Herbal medicine commonly used against infectious diseases in the tropical island of Mauritius. Journal of Herbal Medicine, 2012;2:113-125.

3. Silva NCC, Fernandes JA. Biological properties of medicinal plants: A review of their antimicrobial activity. The Journal of Venomous Animals and Toxins including Tropical Diseases. 2010;16(3):402-413. 
4. Arbonnier M. Trees, shrubs and lianas of West African dry zones. Margraf Publishers, Paris, France; 2004.

5. Titanji VP, Zofou D, Ngemenya MN. The antimalarial potential of medicinal plants used for the treatment of malaria in Cameroonian folk medicine. African Journal of Traditional Complementary and Alternative Medicines. 2008;5:302-321.

6. Joseph B, Raj SJ. Phytopharmacological and phytochemical properties of three Ficus species - An overview. International Journal of Pharmacy and Biological Sciences. 2010;1:246-253.

7. Odebiyi OO, Sofowora EA. Phytochemical screening of Nigerian medicinal plants. Lloyd. 1978;41(3):234-246.

8. Trease GE, Evans MC. Pharmacognosy (14 ${ }^{\text {th }}$ Ed.). New Delhi, India: Elsevier; 2005.

9. Harborne JB. Phytochemical methods. A guide to modern techniques of plant analysis $\left(3^{\text {rd }}\right.$ Ed.). New Delhi: Springer Pvt. Ltd.; 2005.

10. Schinor EC, Salvador MJ, Ito IZ, Dias DA. Evaluation of the antimicrobial activity of crude extracts and isolated constituents from Chresta scapigera. Brazilian Journal of Microbiology. 2007;38:145-149.

11. Manach C, Scalbert A, Morand C, Rémésy C, Jiménez L. Polyphenols: Food sources and bioavailability. American Journal of Clinical Nutrition. 2004;79(5):727-747.

12. Miyasaki Y, Rabenstein JD, Rhea J, Crouch ML, Mocek UM, Kittell PE, et al. Isolation and characterization of antimicrobial compounds in plant extracts against multidrug-resistant Acinetobacter baumannii. PLOS ONE. 2013;8(4): e61594.

13. Manganyi MC, Regnier T, Olivier El. Antimicrobial activities of selected essential oils against Fusarium oxysporum isolates and their biofilms. South African Journal of Botany. 2015;99:115-121.

14. Tadeg $\mathrm{H}$, Mohammed $\mathrm{E}$, Asres $\mathrm{K}$, Gebre-Mariam T. Antimicrobial activities of some selected traditional Ethiopian medicinal plants used in the treatment of skin disorders. Journal of Ethnopharmacology. 2005;100:168-175.

15. Modarresi-Chahardehi A, Ibrahim D, Fariza-Sulaiman S, Mousavi L. Screening antimicrobial activity of various extracts of Urtica dioica. Revista de Biología Tropical, 2012;60(4):1567-1576.

16. Momoh AO, Oladunmoye MK, Adebolu TT. Evaluation of the Antimicrobial and Phytochemical Properties of Oil from Castor Seeds (Ricinus communis Linn). Bulletin of Environment, Pharmacology and Life Sciences. 2012;1(10):21-27.

17. Madigan MT, Martinko JM. Brock biology of microorganisms. New Jersey, USA, Pearson-Prentice Hall; 2006

18. Raza MW, Shad A, Pedler SJ, Karamat KA. Penetration and activity of antibiotics in brain abscess. Journal of the College of Physician and Surgeons Pakistan. 2005; 15(3):165-167.

(c) 2017 Awala et al.; This is an Open Access article distributed under the terms of the Creative Commons Attribution License (http://creativecommons.org/licenses/by/4.0), which permits unrestricted use, distribution, and reproduction in any medium, provided the original work is properly cited.

Peer-review history:

The peer review history for this paper can be accessed here: http://sciencedomain.org/review-history/19031 